\title{
Implications of HAM/TSP functional incapacity in the quality of life
}

\author{
Marcia Shublaq ${ }^{1,2}$, Marco Orsini ${ }^{3}$, Marzia Puccioni-Sohler ${ }^{1,4}$
}

\begin{abstract}
Objective: To identify the functional status and quality of life of HAM/TSP patients. Method: We evaluated prospectively $30 \mathrm{HAM} / \mathrm{TSP}$ patients (20 females) seen in the Neuroinfection Clinic of the HUGG. The functional capacity was analyzed by the functional independence measure (FIM), the expanded disability status (EDSS) scale and the Osame's motor disability score (OMDS). The quality of life was assed by the Short-Form Health Survey 36 (SF-36) $)^{\mathrm{TM}}$. Results: All patients need assistance device. The FIM, OMDS and EDSS scores classified $70 \%, 67 \%$ and $67 \%$ of the patients as dependent, respectively. The lowest scores of the SF-36 survey were found in the domains related to the physical health (D1, D2), role-emotional functioning (D7) and social functioning (D6). Conclusion: Our data suggest that the HAM/TSP physical impairment has an impact in the emotional and social issues, considering the limitation in the daily activities.
\end{abstract}

Key words: HAM/TSP, myelopathy, functional capacity, quality of life.

Implicações da incapacidade funcional na qualidade de vida de pacientes com HAM/TSP

\section{RESUMO}

Objetivo: Avaliar a capacidade funcional e sua interferência na qualidade de vida de pacientes com HAM/TSP. Método: Foram analisados prospectivamente 30 casos (20 mulheres) de HAM/TSP, atendidos no Ambulatório de Neuroinfecção do HUGG. As escalas para avaliação da capacidade funcional consistiram em: medida de independência funcional (FIM), escala de incapacidade expandida (EDSS) e pontuação da incapacidade motora de Osame (OMDS). A qualidade de vida foi analisada pelo Short-Form 36 Health Survey (SF-36) ${ }^{\mathrm{TM}}$. Resultados: Todos os pacientes necessitavam de assistência para deambular. As escalas FIM, OMDS e EDDS classificaram 70\%, 67\% e 67\% dos pacientes como dependentes, respectivamente. A avaliação pelo SF-36 demonstrou menores escores nos domínios físico (D1, D2), emocional (D7) e social (D6). Conclusão: Os achados sugerem que a limitação nas atividades diárias decorrentes do envolvimento físico comprometem aspectos emocionais e sociais na HAM/TSP.

Palavras-chave: HAM/TSP, mielopatia, capacidade funcional, qualidade de vida.

\section{Correspondence}

Marcia Silva Shublaq

Rua Barão da Torre 19 / 101

22411-001 Rio de Janeiro RJ - Brasil

E-mail: imshublaq@yahoo.com.br

\section{Support}

Prof. Puccioni-Sohler received research support from Fundação de Amparo a Pesquisa do Rio de Janeiro (FAPERJ), Project n. E-26/ 110.305/2008

Received 24 April 2010

Received in final form 27 September 2010 Accepted 5 October 2010 imately 15-20 million people worldwide are infected with HTLV-I. The HTLVI seroprevalence ranges from 0.3 to 1.8 in Brazilian asymptomatic blood donors (in São Paulo and Salvador, respectively). The transmission occurs by contaminated blood products, sexual contact and from an infected mother to child through perinatal exposure or breast-feeding ${ }^{2,4}$.

'Neuroinfection Clinic, Gaffrée e Guinle Hospital/Federal University of State of Rio de Janeiro (HUGG/UNIRIO) Rio de Janeiro

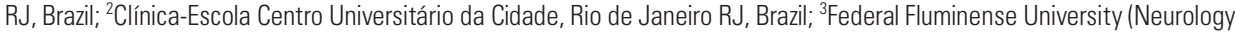
Service) and Faculty of Medicine, Grande Rio University, Rio de Janeiro RJ, Brazil; ${ }^{4}$ CSF Laboratory/Serviço de Patologia Clínica SPC/Federal Clementino Fraga Filho University Hospital/Federal University of Rio de Janeiro (HUCFF/UFRJ), Rio de Janeiro RJ, Brazil. 
A progressive spastic paraparesis or paraplegia is the main clinical finding of HAM/TSP causing important gait impairment and functional disability ${ }^{1-6}$. Low back pain and sphincter disturbance are common complains ${ }^{5}$. A sensory level may also be observed ${ }^{1-3}$.

A set of functional assessment measure has been used to evaluate the grade of gait impairment, disability and functional status of the patients with neurological disorders. Functional independence measure (FIM) is applied to assess physical and cognitive disability ${ }^{7,8}$. The expanded disability status scale (EDSS) assess patients disability ${ }^{9}$. The Osame's motor disability score (OMDS) grades the motor dysfunction in relation to the gait disturbance ${ }^{10}$. The medical outcomes study short form-36 health survey (SF-36) is the instrument used to assess quality of life ${ }^{11,12}$.

This study identifies the functional status of HAM/ TSP patients through the comparison of functional assessment tools. We also evaluated the quality of life of HAM/TSP patients.

\section{METHOD}

Thirty HAM/TSP patients (diagnosed according Osame's criteria, 1991) were seen prospectively in the Neuroinfection Outpatient Clinic of the HUGG/ UNIRIO, Rio de Janeiro, from February 2008 to February 2009. All had a slowly progressive spastic paraparesis associated with the presence of HTLV-1 antibodies in serum and cerebrospinal fluid (CSF), by ELISA technique, confirmed by Western blot in serum ${ }^{1,6}$.

The FIM, EDSS, OMDS and the SF-36 survey were applied to the 30 patients. The FIM score identifies two groups of patients: [1] functional dependent subjects (FIM scores $\leq 108$ ); [2] functional independent (FIM score $\geq 109$ ). The total score ranges from 18 to $126^{7,8}$. Situations of patients functionally independent (without the need from another person), but using an assistance device were considered as modified independency (cut point FIM of 109). The same proceeding was taken to EDSS and OMDS. For EDSS and OMDS, score $\leq 6$ classified the patients as independent and scores above 6 , as dependent. The EDSS score $<6$ corresponds to a patient who is able to walk with bilateral support. EDSS total score ranges from zero (normal) to 10 (complete incapacity $)^{9}$. The OMDS score $\leq 6$ indicates that the patient is able to walk 100 meters using an assistance device. OMDS ranges from zero (normal walking and running) to 13 (complete bedridden) ${ }^{10}$.

Short-form health survey 36 (SF-36) for quality of life consists of 36 item organized in eight domains or dimensions: D1-physical functioning (physical activities, including bathing or dressing), D2-role-physical functioning (work or other daily activities as a result of phys- ical health), D3-bodily pain, D4-general health (evaluation of personal health), D5-vitality (feelings of pep and energy all of the time), D6-social functioning (interference with normal social activities due to physical and emotional problems), D7-role-emotional functioning (problems with work or other daily activities as a result of emotional problems) and D8-mental health (feelings of nervousness and depression or peaceful, happy, and calm all of the time). The first four domains are associated with physical health, and the last four, with mental health. The total score ranges from zero (worst) to 100 (best) ${ }^{11,12}$.

Kappa statistic was utilized to verify the level of concordance among the instruments. The values of kappa statistic range from 0 to 3 , value of 0 corresponding to a concordance not higher than random and the value of 1 , represents a perfect concordance. The meaning of these values are expressed as 0 poor, 0.1 to 0.2 discrete, 0.21 to 0.4 considerable, 0.41 to 0.6 moderate, 0.61 to 0.8 substantial, 0.81 to 1 excellent.

All applicable institutional and governmental regulations concerning the ethical use of human volunteers were followed during the course of this research. The protocol was approved by the HUGG ethical committee under the number 60/2007. All the patients signed informed consent, after the study's procedures were fully explained.

\section{RESULTS}

The studied group consisted in 20 female and 10 male, mean age of 54.2 years $(\mathrm{SD} \pm 10.4)$, ranging from 37 and 77 years, mean time of symptoms of 10.6 years $(\mathrm{SD} \pm 7.6)$, ranging from 1 to 28 years. The most frequently symptoms of onset included lower limb muscle weakness (38\%), sphincter disturbances (34\%) and lower limb paraesthesia (22\%). Low back pain (4\%) and constipation (3\%) were seen rarely. All patients need support. Functional assessment showed that 14 patients (46\%) used a wheelchair, eight patients (27\%) used a single arm crutch and eight patients used two arm crutches. The FIM score presented 70\% (21/30) of the patients as dependent (FIM scores $\leq 108$ ), and the EDSS or OMDS pointed $67 \%(20 / 30)$ as dependent in walking (EDSS or OMDS 26) (Table). Kappa statistics was calculated to measure the level of concordance for the instruments and presented the following coefficients: $\mathrm{EDSS} \times \mathrm{OMDS}=0.55$; $\mathrm{OMDS} \times \mathrm{FIM}=0.20$; and $\mathrm{EDSS} \times \mathrm{FIM}=0.25$ indicating a moderate concordance between EDSS and OMDS and a considerable level between EDSS and FIM.

The SF-36 survey dimensions to assess quality of life scores were also calculated (Table). All had impairment of the quality of life in physical and mental health. The scores domains were lower than 100 in all HAM/TSP patients. From the eight domains, physical functioning (D1), 
Table. Functional incapacity scales and distribution of SF-36 domains in $30 \mathrm{HAM} / \mathrm{TSP}$ patients.

\begin{tabular}{ll}
\hline Functional measures & Mean \pm SD \\
\hline EDSS & $6.6 \pm 0.7$ \\
FIM & $6.6 \pm 0.7$ \\
OSAME & $8 \pm 2.4$ \\
Quality of life Issue (SF-36 Domains) & \\
D1- Physical functioning & $14.7 \pm 8.7$ \\
D2 - Role-physical functioning & $19.2 \pm 21.5$ \\
D3 - Bodily pain & $60.8 \pm 29.5$ \\
D4 - General health & $39 \pm 14.4$ \\
D5 - Vitality & $52.2 \pm 21.6$ \\
D6 - Social functioning & $47.1 \pm 21.2$ \\
D7 - Role-emotional functioning & $18.9 \pm 33.5$ \\
D8 - Mental health & $61.1 \pm 22.2$ \\
\hline
\end{tabular}

SD: standard deviation; EDSS: expanded disability status scale; FIM: functional independence measure; OSAME: Osame's motor disability score; FIM scores $\leq 108$ : functional dependent; EDSS and OMDS scores $\geq 6$ : dependent. The SF-36 score ranges from zero (worst) to 100 (best).

role-physical functioning (D2) and role-emotional functioning presented the lowest mean scores (mean $<20$ ), followed by the impairment of social functioning (D6).

\section{DISCUSSION}

There are few studies about the functional issues in HAM/TSP patients ${ }^{13-18}$. Gait independence is an important issue to functional independency. All our HAM/ TSP patients use assistance devices, although some of them are independent according of functional assessment measures (30\% in FIM score and 33\%, in EDSS and Osame's scores). This is considered a modified independence and describes a patient that uses an assistance device but do not need supervision or help from another person in functional activities as gait. Lannes et al. ${ }^{18}$ describe the gait disturbance for the HAM/TSP patients as a result of the hypertonicity of the lower members' muscles including the pelvic groups. This would affect the synergy between scapular and pelvic griddles. Reduction of muscle strength, increase of the muscle tonus, fatigue and pain are pointed as factors that affect the gait pattern. These can also interfere gradually on the use of assistance devices specially the arm crutches. When considering the symptoms of onset, $38 \%$ of the patients complained of muscle weakness of the lower limb muscle.

A previous study evaluated the disability profile of 72 Brazilian HAM/TSP patients, using FIM scale ${ }^{16,17}$. They found the lowest items scores in locomotion and bladder management. These data are in according with the main complains of our HAM/TSP patients. The FIM scale was originally designed to estimate overall burden of care ${ }^{7,8}$. In our study we found FIM mean score of 95
( $\mathrm{SD} \pm 18.8$ ), pointing $70 \%$ of the patients as dependent. The use of arm crutches (54\%), specially the bilateral use, makes hard to complete daily activities as brushing teeth, taking shower, use the toilet and cook while standing. The grade of impairment of these activities may turn necessary the assistance from another person or the use of any other device. Two patients got FIM score higher than 112 (indicating independence) although both depend on a wheelchair. They considered themselves independent in all of the activities of daily life, needing assistance only to take shower and dress the lower part of the body. The occurrence of bladder incontinency makes it harder to complete these activities and to participate in social and work events, reducing the satisfaction and the quality of life perceived by the patient.

The other two instruments also pointed the gait dependency as the main functional disturbance. The EDSS mean score of $6.5(\mathrm{SD} \pm 0.6)$ points $67 \%$ of the patients as dependent in walking and the OMDS mean score of 8 $(\mathrm{SD} \pm 2.4)$ points it too. EDSS is currently the most used assessment instrument in clinical trials ${ }^{9}$. OMDS score of 5 indicates one hand support needed to walk and score of 9 indicates that the patient is unable to walk (crawls on hands and knees $)^{10}$. Gait progression reported by the OMDS has been considered as a valid instrument ${ }^{13,15}$

Kappa statistics was calculated to measure the level of concordance for the instruments and presented the highest coefficient between EDSS and OMDS, a moderate concordance.

The SF-36 survey presented the lowest values for the domains D1 (physical functioning), D2 (role-physical functioning) and D7 (role-Emotional). It suggests that the physical impairments and dependence impact the emotional status. Since values greater than 50 indicate a better condition, it is possible to verify that cognitive capacity is not usually affected (D8), and being so, the commitment is discrete as pointed in the patients' reports of the first symptoms and signs of the disease.

Our data point that the lack of functional independency, specially the progressive, invalidating gait disturbance compromises physical, emotional and social issues and can modify the perception of quality of life. In fact, the lack of functional independence for the activities of daily life compromises the quality of life. The measurements used in this study describe the most of the patients as dependent, and the impact of dependency functional status is demonstrated in the quality of life score.

\section{REFERENCES}

1. Osame M. Review of WHO Kagoshima meeting and diagnostic guidelines for HAM/TSP. In: Blattner WA (Ed). Human retrovirology: HTLV. New York: Raven Press, 1990:191-197.

2. Osame M. Pathological mechanisms of human T-cell lymphotropic virus type I - associated myelopathy (HAM/TSP). J Neurovirol 2002;8:359-364. 
3. De Castro-Costa CM, Araújo AQ, Barreto MM, et al. Proposal for diagnostic criteria of tropical spastic paraparesis/HTLV-I-associated myelopathy (TSP/ HAM). AIDS Res Hum Retroviruses 2006;22:931-935.

4. Carneiro-Proietti ABF, Ribas JGR, Catalan-Soares C, et al. Infecção e doença pelos vírus linfotrópicos humanos de células T (HTLV-I/II) no Brasil. Rev Soc Bras Med Trop 2002;35:499-508

5. Walton GW, Kaplan AS. Urinary dysfunction in tropical spastic paraparesis: preliminary urodynamic survey. J Urol 1993;150:930-932.

6. Puccioni-Sohler M, Rios M, Carvalho SM, et al. Diagnosis of HAM/TSP based on CSF proviral HTLV-I DNA and HTLV-I antibody index. Neurology 2001;57:725-727.

7. Dodds TA, Martin DP, Stolov WC, Deyo RA. A validation of the functional independence measurement and its performance among rehabilitation inpatients. Arch Phys Med Rehabil 1993;74:531-536.

8. Ribeiro M, Miyazaki MH, Jucá SSH, Sakamoto H, Pinto PPN, Battistella LR. Validação da versão brasileira da Medida de Independência Funcional. Acta Fisiatr. São Paulo 2004;11:72-76.

9. Kurtzke JF, Beebe GW, Nagler B, et al. Studies on the natural history of multiple sclerosis. J Chron Dis 1977;30:819-830.

10. Izumo S, Goto I, Itoyama Y, et al. Interferon Interferon-alpha is effective in HTLV-I-associated myelopathy: a multicenter, randomized, double-blind, controlled trial. Neurology 1996:46:1016-1021.

11. Janssens AC, Van Doorn PA, De Boer JB, Van Der Meché FG, Passchier J,
Hintzen RQ. Impact of recently diagnosed multiple sclerosis on quality of life, anxiety, depression and distress of patients and partners. Acta Neurol Scand 2003;108:389-395

12. Mendes FM, Balsimelli S, Stangehaus G, Tilbery PT. Validação de escala de determinação funcional da qualidade de vida na esclerose múltipla para a língua portuguesa. Arq Neuropsiquiatr 2004;62:108-113.

13. Alarcón-Avilés T, Alarcón-Guzmán T, Román CG. Infección neurológica por HTLV-I. Rev Ecuat Neurol 2001;10:76-80.

14. Alarcón-Guzmán T, Alarcón-Avilés T. Tratamiento de la paraparesia espástica tropical con pentoxifilina: estudio piloto. Rev Ecuat Neurol 2002; $1: 1-2$.

15. Figueroa EM, Remondegui C, Valdez M, Pintado A. Paraparesia espástica tropical na província de Jujuy. Cadernos de la Facultad de Humanidades y Ciências Sociales 2004;22:273-286.

16. Franzoi AC, Araújo AQC. Disability profile of patients with HTLV1 associated myelopathy/tropical spastic paraparesis using the functional independence measure (FIM). Spinal Cord 2005;43:236-240

17. Franzoi AC, Araujo AQ. Disability and determinants of gait performance in HAM/TSP. Spinal Cord 2007;45:64-68.

18. Lannes P, Neves MAO, Machado DCD, Silva JG, Bastos VHV. Paraparesia espástica tropical: mielopatia associada ao HTLV-I: possíveis estratégias cinesioterapêuticas para melhorar padrões de marcha em portadores sintomáticos. Rev Neurocienci 2006;14:153-160. 